\title{
Central Melanocortins and the Regulation of Weight During Acute and Chronic Disease
}

\author{
Daniel L. Marks* and Roger D. Cone ${ }^{\dagger}$ \\ *Department of Pediatric Endocrinology, 'The Vollum Institute, \\ Oregon Health Sciences University, Portland, Oregon 97201
}

\begin{abstract}
Recent advances in our understanding of the regulation of body weight, appetite, and metabolic rate have highlighted the role of the adipose-derived hormone leptin and its receptor as fundamental modulators of these processes. Investigations of the neural targets for leptin action - as well as characterization of the agouti obesity syndrome - have, in turn, led to the discovery of fundamental neural pathways involved in the central regulation of energy homeostasis. In particular, the central melanocortin system has been shown to regulate appetite and metabolic rate in rodents; mutations in this system have been demonstrated to result in obesity in humans. Overall, the melanocortin system appears to function as a bidirectional rheostat in the regulation of energy intake and expenditure in rodents and potentially in humans. The first section of this chapter will focus on the development of our understanding of melanocortin physiology in the context of obesity. In particular, recent data regarding the interplay between melanocortin and neuropeptide Y (NPY) signaling at a cellular level will be discussed. The following section will discuss the hypothesis that melanocortin signaling plays a role in pathological weight luss and hypermetabolism observed in murine cachexia models. The potential role of this system in integrating a variety of anorexic and cachexic signals, as well as the potential for its pharmacological manipulation in the treatment of human cachexia, will be discussed.
\end{abstract}

\section{The Central Melanocortin System and Energy Homeostasis}

\section{A. INTRODUCTION}

The last decade has witnessed significant advances in our understanding of energy homeostasis and regulation of body weight. The recent cloning and characterization of the genes responsible for obesity syndromes in the mouse - fatty, tubby, obesity, diabetes, and agouti - had led to our current understanding of the role of the adipocyte hormone leptin and its receptor in the feedback regulation of appetite and metabolic rate (Chua et al., 1996; Tartaglia et al., 1995; Zhang et al., 1997). Furthermore, we have started to unravel the neuronal pathways that mediate many of the effects of leptin and exert central control over processes fundamental to the intake, use, and storage of body fuels. In particular, the cloning of the agouti gene (Buitman et al., 1992; Miller et al., 1993) and the discovery of 
its mechanism of action (Fan et al., 1997; Huszar et al., 1997; Lu et al., 1994) led to the identification of a set of neuronal pathways that we will refer to as the melanocortin system. In general, the melanocortin system can be defined as the hypothalamic and brainstem neurons expressing pro-opiomelanocortin (POMC), the hypothalamic neurons coexpressing neuropeptide Y (NPY) and the melanocortin antagonist agouti-related protein (AGRP), and the neurons downstream of these systems. For the purposes of this chapter, these downstream neurons will be defined by the presence of the two primary central melanocortin receptors, melanocortin 3 receptor (MC3-R) (Roselli-Rehfiss et al., 1993) and melanocortin 4 receptor (MC4-R) (Mountjoy et al., 1994).

\section{B. LEPTIN AND ENERGY HOMEOSTASIS}

Leptin is secreted by adipocytes. It regulates adiposity and metabolic rate by reducing food intake and increasing energy expenditure (Campfield et al., 1995; Halaas et al., 1995; Pelleymounter et al., 1995; Zhang et al., 1994). Experimental elevation of leptin within the physiological range produces weight loss and relative anorexia, while decreased leptin levels lead to the complex neuroendocrine response that occurs during starvation (Ahima et al., 1996; Halaas et al., 1997). Numerous studies of leptin levels in humans of various age groups and disease states have been published (for review, see Roemmich and Rogol, 1999). In normal infants, school-aged children, and adolescents, the normative range of serum leptin varies with age and becomes sexually dimorphic during adolescence. Within groups matched for age and gender, leptin levels are directly proportional to body fat mass, as reflected in the calculated body mass index (BMI) or measured with other methods (Blum et al., 1997; Clayton et al., 1997; Roemmich and Rogol, 1999). Given that elevations in circulating leptin would normally result in anorexia and weight loss, the elevated leptin concentrations consistently found in obese individuals have been interpreted as an indication of leptin resistance (Considine et al., 1996). Diseases associated with malnutrition - including anorexia nervosa, Crohn's disease, cystic fibrosis, and acquired immune deficiency syndrome (AIDS) - confer low leptin levels. This highlights the energy-conserving role of leptin in regulating the neuroendocrine response to starvation (Ahima et al., 1996). The possibility that a primary defect in leptin expression may lead to human disease was confirmed in studies of highly inbred kindreds with extreme obesity (Montague et al., 1997; Ozata et al., 1999).

However, human leptin deficiency is extremely rare. The obesity syndrome that results bears little resemblance to the polygenic obesity that has become epidemic in our society. In humans, leptin deficiency results primarily in a combination of extreme hyperphagia, hypogonadism, and decreased sympathetic tone, with some suggestion of immune dysfunction as well (Farooqi et al., 1999; Montague et al., 1997; Ozata et al., 1999). In the mouse, hypercorticosteronemia, 
hypometabolism, and hyperinsulinemia also are observed and result in impaired growth of bone and lean tissue (Ahima et al., 1996; Ozata et al., 1999).

\section{MELANOCORTIN OBESITY SYNDROMES AND CENTRAL MELANOCORTIN RECEPTORS}

Several observations have led to the proposal that disruption of appropriate melanocortin signaling may be a more-common cause of obesity in humans. First, as will be described, the disruption of melanocortin signaling in various rodent models recapitulates the various features observed in obese individuals. Second, obesity syndromes involving defects in two different steps in the melanocortin pathway have been described in humans. One of these syndromes represents the most-common monogenic form of obesity yet described. Specifically, families with rare, deleterious mutations in the POMC gene have been described in whom the defect results in a syndrome of red hair, corticotropin (ACTH) deficiency, and obesity (Krude et al., 1998). Heterozygous mutations in MC4-R have been reported to be associated with common pediatric obesity (Vaisse et al., 1998; Yeo et al., 1998). Another group has demonstrated strong genetic linkage of obesity to the POMC locus on chromosome 2p21, although no defects in the coding region of the gene were found (Comuzzie et al., 1997). Collectively, these data argue strongly that the melanocortin system plays a role in the regulation of energy homeostasis in mice and humans.

Among the multiple gene mutations that lead to an obese phenotype in mice, the dominantly inherited lethal yellow mouse $\left(A^{Y} /-\right)$ exhibits a phenotype that is most reminiscent of common human obesity. These mice are hyperphagic, have an efficient metabolism, and develop insulin resistance as they age (Frigeri et al., 1983,1988; Michaud et al., 1994; Yen et al., 1994). These animals have normal reproductive and adrenal axies (Wolff and Flack, 1971) and increased somatic growth (Wolff, 1963), features that are found in the development of obesity in humans. The basis for this phenotype was found to be due to a genetic rearrangement that led to the constitutive and ubiquitous expression of the agouti peptide, a paracrine factor that is normally involved in regulation of pigmentation (Bultman et al., 1992). Agouti was shown to be an antagonist of melanocortin signaling at the MC-1 receptor on pigment cells. There, it functioned to block the melanocyte-stimulating hormone (MSH)-stimulated synthesis of eumelanin ( $\mathrm{Lu}$ et al., 1994), thereby explaining the yellow coat color seen in this strain (Bultman et al., 1992; Duhl et al., 1994; Miller et al., 1993). Remarkably, agouti also was found to be a specific, high-affinity antagonist of the hypothalamic MC4-R ( $\mathrm{Lu}$ et al., 1994). In this model, both agouti and MC4 receptor mRNAs were present in areas of the hypothalamus known to be involved in feeding behavior. This led to our proposal that aberrant antagonism of the central MC4-R was the direct cause of the agouti obesity syndrome. Investigations using a $\mathrm{MC} 4$ receptor antagonist, 
SHU9119, confirmed this hypothesis by demonstrating an increase in feeding behavior in animals injected intracerebroventricularly (ICV) with this compound (Fan et al., 1997). Furthermore, ICV injection of the small $\alpha-\mathrm{MSH}$ agonist, MTII, inhibited feeding behavior. This inhibition of feeding behavior could be reversed by administration of SHU9119. The antagonist data argue that the endogenous POMC neurons exert a tonic inhibitory effect on feeding and energy storage via their release of desacetyl- $\alpha$-MSH, the primary melanocortin cleavage product in the brain, at downstream sites containing MC4-R.

The importance of melanocortinergic neurons and the MC4-R in the regulation of feeding behavior was reinforced with the targeted disruption of the MC4-R (Huszar et al., 1997). Homozygous knockout animals recapitulated all of the primary metabolic, growth, and behavioral phenotypes of the agouti obesity syndrome. Furthermore, mice heterozygous for the MC4-R are more obese than wild-type mice, suggesting that a decrease in MC4-R number would lead to obesity. Thus, the MC4-R appears to function as a rheostat that can provide the bidirectional tuning necessary to maintain relative energy stability in a variety of environmental conditions.

Investigation of the agouti obesity syndrome led to the cloning and characterization of AGRP, an endogenous, hypothalamic, melanocortin receptor antagonist (Fong et al., 1997; Ollmann et al., 1997). The function of AGRP as an endogenous melanocortin receptor antagonist was demonstrated when its ectopic expression in transgenic mice was found to cause an obesity syndrome analogous to that seen in the MC4-RKO animal (Ollmann et al., 1997). The pattern of AGRP expression and release is also consistent with its role as a melanocortin antagonist. It is expressed in high levels almost exclusively in the arcuate nucleus cell bodies that project to MC4-R-expressing neurons in areas such as the dorsomedial hypothalamus (DMH), the paraventricular nucleus (PVN), and the septal region (Haskell-Luevano et al., 1999). Furthermore, AGRP expression is robustly stimulated by fasting and inhibited by leptin (Broberger et al., 1998; Chen et al., 1999; Mizuno and Mobbs, 1999; Shutter et al., 1997), bolstering the argument that its primary role is as an endogenous melanocortin antagonist.

\section{CELLULAR INTEGRATION OF OREXIGENIC AND ANOREXIGENIC SIGNALS}

Interestingly, it appears that most AGRP neurons coexpress NPY (Broberger et al., 1998; Smith, 1993), a molecule with well-described effects on energy homeostasis (for review, see Kalra et al., 1999). NPY is produced in hypothalamic nuclei known to regulate appetite and metabolism. It is a potent orexigen when injected centrally (Baskin et al., 1999; Billington et al., 1991; Blasquez et al., 1995; Gerald et al., 1996; Larsen et al., 1997; Stanley et al., 1985). The role of NPY in the feedback effects of leptin first was indicated by observations that leptin 
deficiency resulted in a significant upregulation of NPY expression, while leptin administration caused a decrease in expression (Stephens et al., 1995; Wilding et al., 1993). The role of NPY in mediating leptin feedback was bolstered further by the observation that genetic deletion of NPY in leptin-deficient animals resulted in a significant decrease in their degree of obesity (Erickson et al., 1996). In general, it appears that NPY synthesis and secretion are upregulated in most models of energy deficiency or increased metabolic demand (Inui, 1999b; Smith, 1993). Thus, a decrease in the level of NPY expression was proposed as one potential mechanism for the anorexic effects of leptin. The demonstration that the arcuate POMC (Cheung et al., 1997) and NPY/AGRP (Hakansson et al., 1996) neurons express the leptin receptor strengthened this argument and led us to propose that effector neurons downstream of leptin receptors would functionally integrate NPY and melanocortin signals (Cowley et al., 1999). The output of these effector neurons would vary, depending on their identity, with the overall effect being the complex behavioral and metabolic response seen with alterations in leptin levels.

Anatomical support for this idea was derived from confocal microscopic analysis, which clearly demonstrated neuronal fibers containing both NPY and AGRP and neuronal fibers containing $\alpha$-MSH adjacent to single-cell bodies within the $\mathrm{mpPVH}$, as well as the presence of MC4-R immunoreactivity (IR) within the same region (Cowley et al., 1999). Interestingly, MC4-R IR was found primarily on the terminals of axons in the section of the PVH that was studied, implying that MC4-R activity may be presynaptic.

Functional antagonism of melanocortin agonists and NPY within the PVH also was demonstrated in this study. Here, microinjections of SHU9119 (a MC3/MC4-R antagonist) and MTII (a MC3/MC4 agonist) into the PVH were first shown to have opposing actions on food intake and oxygen consumption. As expected from previous work, SHU9119 not only prevented the MTII-induced inhibition of feeding but also produced a stimulation of feeding when injected alone. This is consistent with the idea that melanocortin peptides provide a tonic inhibition of food intake via their binding to MC4-R in the hypothalamus. Demonstration of the potent effect of unilateral PVH injections of these compounds was followed by an analysis of the functional interaction between NPY and MTII in this brain region. PVH microinjections of NPY produced the expected potent orexigenic activity. However, preinjection of MTII 10 minutes prior to the NPY injection completely suppressed the orexigenic effect of NPY. The ability of MTII microinjection into the PVH to stimulate oxygen consumption was demonstrated in this study. This observation, combined with previous demonstration of a decrease in energy expenditure with PVN NPY microinjection (Billington et al., 1991; Egawa et al., 1991), argues strongly that information from POMC and 
NPY/AGRP neurons can be functionally integrated within the PVH to regulate both feeding and energy expenditure.

To further explore the cellular basis for this interaction, whole-cell recordings were made from mpPVH neurons in brain slice preparations. The neurons were chosen on the basis of a predominant inhibitory synaptic response to local electrical stimulation, recorded as an outward synaptic current (IPSC). In the region of the PVH studied, nearly 80 percent of neurons showed a modification of this IPSC in response to bath application of NPY or a melanocortin agonist. The application of MTII (10 nM) resulted in a significant increase in current amplitude $(25 \%+4 \%)$, with an $\mathrm{EC}_{50}$ of $1.4 \mathrm{nM}$. In 23 of 24 of the cells responsive to MTII, NPY caused a significant inhibition of the IPSC $(29 \%+3 \%)$. These effects were shown to be specific, as bath application of SHU9119 blocked the effect of MTII but had no effect on the inhibition brought about by NPY application. Furthermore, the effects of the synthetic melanocortin agonist and antagonist were identical to those seen with applications of the endogenous ligands, $\alpha-\mathrm{MSH}$ and AGRP, respectively. Further studies employed specific channel agonists and antagonists to demonstrate that the IPSC being studied in these cells was due to alterations in gamma aminobutyric acid (GABA) release and that this effect was mediated at a presynaptic level. Collectively, these observations led to the construction of a theoretical general model for the cellular integration of NPY/AGRP signals with melanocortin signals. Obviously, other orexigenic and anorexigenic neuropeptides and neurotransmitters will play a role in modulating the effector neurons. The area of the PVH studied is unlikely to be the sole site of integration of these signals, since melanocortin effects on feeding and metabolism have been demonstrated within the brainstem (Grill et al., 1998). Nonetheless, these data provide the first direct evidence of a functional cellular integration of these two crucial neural mediators of appetite and metabolic efficiency.

\section{The Role of Melanocortins in Anorexia and Cachexia}

\section{A. THE ROLE OF CYTOKINES}

The role of nutrition and balanced metabolism in normal growth and development is well known. Individuals affected with either acute or chronic diseases often show disorders of nutrient balance. Furthermore, children may have no obvious organic disease, yet gain weight poorly, resulting in the observational diagnosis of failure to thrive. In some cases, a devastating state of malnutrition known as cachexia arises, brought about by a synergistic combination of a dramatic decrease in appetite and an increase in metabolism of fat and lean body mass. This combination is found in a number of disorders, including cancer, cystic fibrosis, AIDS, rheumatoid arthritis, congestive heart failure, and renal failure 
(Tisdale, 1997). The severity of cachexia in these illnesses is often the primary determining factor in both quality of life and eventual mortality (Larkin, 1998; Tisdale, 1997). Indeed, body mass retention in AIDS patients has a stronger correlation with survival than any other current measure of the disease (Kotler et al., 1989). This has led to intense investigation of cachexia and the proposal of numerous hypotheses regarding its etiology. At this point, most authors suggest that cytokines released during inflammation and malignancy act on the central nervous system (CNS) to alter the release and function of a number of key neurotransmitters, thereby altering both appetite and metabolic rate (Inui, 1999a; Plata-Salaman 1989,1998; Tisdale, 1997).

Support for this mechanism is derived from numerous sources. One model that is particularly useful in studying cachexia is administration of a purified product found in the cell wall of gram-negative bacteria known generically as lipopolysaccharide (LPS). Early experiments focused on the ability of LPS injections to reliably produce anorexia in experimental animals (Baile et al., 1981; Murray and Murray, 1979). It is now known that LPS potently stimulates the release of numerous cytokines from immune cells in the periphery and glia within the CNS (Cavaillon and Haeffner-Cavaillon, 1990; Hillhouse and Mosley, 1993; Molloy et al., 1993; Van Dam et al., 1995). Furthermore, both peripheral and central injections of purified recombinant cytokines can reproduce the behavioral, feeding, and autonomic responses seen with LPS administration (Dinarello, 1996; Masotto et al., 1992; Plata-Salaman, 1998; Plata-Salaman and Borkoski, 1994). Chronic overproduction of cytokines may lead to cachexia when an illness is prolonged. Cytokines such as interleukin-1beta (IL-1 $\beta$ ), interleukin-6 (IL-6), and tumor necrosis factor-alpha (TNF- $\alpha$ ) are upregulated in various animal cachexia models. Neutralization of these factors by genetic or pharmacological methods leads to attenuation of cachexia (Plata-Salaman, 1998; Plata-Salaman and Borkoski, 1994; Sherry et al., 1989; Vallieres and Rivest, 1997; Yasumoto et al., 1995). Finally, chronic infusion of IL-1 $\beta$ or TNF- $\alpha$ causes anorexia, rapid weight loss, and catabolism of body protein stores, analogous to the state observed with chronic illness (Fong et al., 1989; Plata-Salaman et al., 1996).

\section{B. LEPTIN AS A CYTOKINE}

As outlined in section I, leptin is secreted by adipocytes and regulates adiposity and metabolic rate by reducing food intake and increasing energy expenditure (Campfield et al., 1995; Halaas et al., 1995; Pelleymounter et al., 1995; Zhang et al., 1994). Remarkably, leptin is a member of the IL-6 superfamily of proteins and has many biochemical features of a cytokine molecule (Zhang et al., 1994,1997). Using reporter gene analysis, Baumann and colleagues demonstrated that the signaling cascade events downstream of leptin treatment are nearly identical to those of the cytokine IL- 6 and that leptin can act synergistically with other 
cytokines in regulating gene expression (Baumann et al., 1996; Wang et al., 1997). Experimental elevation of leptin within the physiological range produces weight loss and relative anorexia that is similar in character to that seen with administration of other cytokines (Ahima et al., 1996; Halaas et al., 1997). Leptin secretion is increased by both central and systemic immunological challenge and has therefore been proposed as a potential mediator of inflammation-induced anorexia (Finck and Johnson, 1999; Finck et al., 1998; Grunfeld et al., 1996; Sarraf et al., 1997). The mechanism whereby leptin expression and secretion is enhanced during inflammation is complex but has been shown to be mediated by both IL-1 $\beta$ and TNF- $\alpha$ (Grunfeld et al., 1996; Sarraf et al., 1997). Conversely, leptin induces production and release of $1 \mathrm{~L}-1 \beta$ in the brains of normal rats and the release of both IL-1 $\beta$ and TNF- $\alpha$ from mouse macrophages (Loffreda et al., 1998; Luheshi et al., 1999). Collectively, these observations suggest a potential interplay between leptin and other cytokines in the regulation of metabolism and appetite during acute and chronic illness and that they activate similar signaling pathways. However, the observation that both leptin-deficient and leptin receptor-deficient mice have a robust anorexic response to LPS injections highlights the complexity of this system and indicates that cytokines may regulate leptin but also clearly act downstream of the leptin receptor (Faggioni et al., 1997).

\section{CENTRAL REGULATION OF ANOREXIA AND CACHEXIA}

Leptin is thought to exert its effects on feeding and metabolism primarily via regulation of hypothalamic neurons (Baskin et al., 1999; Cheung et al., 1997; Elmquist et al., 1997; Glaum et al., 1997; Jacob et al., 1997; Woods and Stock, 1996). Several neuronal pathways have been identified as targets of leptin action within the hypothalamus. As discussed in section I, several lines of evidence point toward a direct regulation of NPY synthesis and release by alterations in leptin levels brought about by fasting or by experimental manipulation (for review, see Inui, 1999a). This has led, in turn, to the hypothesis that a decrease in the level of NPY expression is responsible for the cytokine-mediated anorexia seen in animal models of inflammation and chronic disease. However, the observations that there was no change - or even an increase in NPY mRNA and peptide expression in tumor-bearing rats, rats with dehydration-induced anorexia, and rats treated with LPS - indicates that downregulation of NPY expression is not a primary stimulus for anorexia in these models (Gayle et al., 1998; Jensen et al., 1998; Plata-Salaman et al., 1998; Watts et al., 1999). A decrease in the response to exogenous NPY in anorexic, tumor-bearing animals has been demonstrated but it is unclear if this represents an effect that is specific to NPY signaling or is a reflection of increased inhibitory tone exerted by another neurotransmitter system (Chance et al., 1996). 
POMC neurons in the arcuate nucleus express the leptin receptor and MC4RKO mice are leptin resistant, leading several investigators to propose that melanocortin neurons mediate the anorexic effects of elevated leptin (Friedman, 1997; Gura, 1997). However, in other studies, it clearly has been shown that the melanocortin system has effects on weight and metabolism that are independent of leptin feedback and that leptin-deficient animals with disrupted melanocortin signaling remain sensitive to leptin administration (Boston et al., 1997; Marsh et al., 1999). Nonetheless, POMC neurons represent a logical target for cytokinemediated feedback on feeding behavior and metabolic control. Preliminary data suggest a role in anorexia and cachexia as well (Huang et al., 1999; Marks et al., 2000 ).

As outlined earlier, POMC neurons are thought to provide an important tonic inhibition of food intake and energy storage, primarily via production and release of $\alpha-\mathrm{MSH}$ from the POMC precursor. Central administration of MC4-R agonists can inhibit energy intake, increase energy expenditure (Cowley et al., 1999; Fan et al., 1997), lower serum insulin (Fan et al., 2000), and reduce body weight (Stair et al., 1999; Patterson et al., 1999). Thus, MC4-R activation results in a physiological response that mirrors that observed when various cytokines, including leptin, are administered or elevated in animals and humans. In addition, the leptin-deficient $o b / o b$ mouse and the leptin receptor-deficient $d b / d b$ mouse remain sensitive to the hypophagic effects of LPS. This implies that the site of integration of this anorexic signal lies downstream of the hypothalamic leptin receptor (Faggioni et al., 1997).

Studies of melanocortin function in cytokine-induced anorexia are complicated by the fact that $\alpha$-MSH is a potent anti-inflammatory and antipyretic when administered centrally. Therefore, it may have effects on feeding that are not specific to the hypothalamus (Adan and Gispen, 1997; Catania and Lipton, 1993; Catania et al., 1992). Furthermore, investigations of the impact of central melanocortins in transducing anorexic signals from cytokines have had mixed results. Blockade of MC4-R signaling has been shown to enhance the anorexia observed when IL $1-\beta$ is administered peripherally (Shimomura et al, 1991) and to diminish the response when administered centrally (Tatro et al., 1999). Huang and colleagues investigated the impact of central administration of $\alpha-\mathrm{MSH}$ or the melanocortin receptor subtype3/subtype4 antagonist SHU-9119 on LPS-induced anorexia and fever in rats (Huang et al., 1999). In this study, the investigators found a significant potentiation of the suppressive effects of LPS on food intake with administration of $\alpha$-MSH and a reversal of LPS-induced anorexia with SHU-9119 administration. These same treatments reduced and increased LPS-induced fever, respectively.

AGRP is an endogenous antagonist of the hypothalamic MC4-R but its role in limiting inhibition of feeding by cytokines has not been reported. However, 
AGRP is robustly regulated in other models of energy imbalance and its anatomical distribution and function make it a logical candidate for transduction of anorexic signals during both acute and chronic illness. We have demonstrated that AGRP administration can prevent the anorexia and hypodipsia brought about with LPS administration (Marks et al., 2000). Furthermore, we have demonstrated that MC4-RKO animals resist LPS-induced anorexia, hypodipsia, and decreased locomotion. Our feeding data are in agreement with those of Huang and colleagues and demonstrate that both genetic and pharmacologic blockade of central MC4-R signaling can prevent the response to induction of a complex and pleotropic cytokine response (Marks et al., 2000). Additionally, we have demonstrated that in young, rapidly growing mice, the weight loss that accompanies LPS-induced illness can be reversed, allowing the animals to continuc to follow a normal growth curve (Marks et al., 2000).

\section{MLLANOCORTINS AND CANCER CACIIEXIA}

Cachexia commonly is observed in patients with cancer, particularly in children and the elderly (Bruera, 1997). The resulting malnutrition and loss of lean body mass reduces the quality of life for the affected individual and compromises recovery by decreasing tolerance to therapy and increasing postsurgical complications (Inui, 1999a; Larkin, 1998). Attempts at drug therapy for cachexia with a variety of agents have met with limited success (DeConno et al., 1998; Windisch et al, 1998; Rivandeneria et al, 1999; McCarthy, 1999). The most-widely utilized agent, megestrol acetate, has shown some promise in reversing weight loss. However, this is primarily due to increases in fat mass and water retention rather than to preservation of lean body mass (Strang, 1997). Various murine models of cancer cachexia exist that recapitulate the anorexia, rapid weight loss, and catabolism of body protein stores found in human cancer patients. Subcutaneous injections of Lewis lung adenocarcinoma (LLA) or various types of methylcholanthrene-induced sarcomas reliably produce cachexigenic tumors in mice, therefore providing useful models for genetic and pharmacologic analysis of this disorder and its potential treatment (Matthys et al, 1991; Llovera et al, 1998; Ushmorov et al, 1999; Svaninger et al., 1987).

NPY has a duration of action that is limited to hours. Its role in multiple other neural processes including seizure kindling may limit the usefulness of NPY agonists in cachexia therapy (Levine and Morley, 1984; Marksteiner and Sperk, 1988). In contrast, several investigators have demonstrated prolonged duration of activity of AGRP, with feeding effects being observed for as long as 2 to 3 days (Dinulescu, 2000; Rossi et al., 1998). $\Lambda$ GRP is not known to produce illness behavior or aversive consequences after injection, perhaps due to the relatively small number of potential activity sites in the brain. These features highlight the potential of AGRP analogs as therapeutic agents in prolonged human illness. 
Overall, if melanocortin signaling is necessary for anorexia or cachexia, then the MC4-R may be an outstanding target for the development of antagonist drugs that would be useful in preventing and treating these conditions.

Recently, we have studied the role of melanocortin receptors in transducing the prolonged metabolic derangement observed in experimental cancer. Previous investigators have demonstrated that tumor-bearing animals frequently die from cachexia and exhaustion of metabolic fuels, rather than from metastasis or infection (Svaninger et al., 1987,1989; Emery et al., 1984; Emery, 1999). Our observations demonstrate that hypophagia and carcass weight loss induced by sarcoma growth can be both reversed and prevented by administration of the endogenous MC3/MC4 antagonist, AGRP (Marks et al., 2000). In these experiments, the duration of the experiment in the AGRP-treated animals was limited only by ethical concerns due to the size of the tumor, rather than by anorexia or lack of physical activity and grooming. Prevention of tumor-induced hypophagia with early and repeated AGRP injections resulted in maintenance of normal food intake. This enhancement of feeding was much greater than the relative hyperphagia observed in the sham-tumor-implanted animals. The inability to completely mimic the feeding observed in the sham-tumor group is likely to reflect, in part, the energy drain imposed by the rapid growth of a metabolically active tissue. However, our observation that the rate of tumor growth was identical between AGRP and a vehicle-treated group argues strongly that tumor growth produces a global metabolic derangement that is mediated to a significant extent by central melanocortin receptor activation. If the tumor simply represented a metabolic sink, increased nutrient intake would be expected to result in increased tumor growth at the expense of nontumor body mass.

\section{Summary}

Recently, great strides have been made in understanding endocrine and neural control of appetite, metabolism, and body weight. In particular, we now know that disorders of leptin feedback or hypothalamic melanocortin signaling can lead to pathological weight gain and diabetes in humans (Clement et al., 1998; Krude $e t$ al., 1998; Montague et al., 1997). While obesity is clearly a major health challenge, other disorders affecting body weight are found in humans, particularly in pediatric populations. Several chronic diseases - including renal failure, cystic fibrosis, AIDS, and various forms of cancer - are associated with weight loss and growth failure. In children with chronic diseases, there appears to be a dysfunctional change in the regulation of appetite and metabolism. Indeed, cachexia, characterized by weight loss and progressive tissue wasting out of proportion to the level of anorexia, is a feature of many of these diseases and contributes significantly to mortality (Tisdale, 1997). Early studies of the role of melanocortin signaling in illness-related anorexia have demonstrated that this 

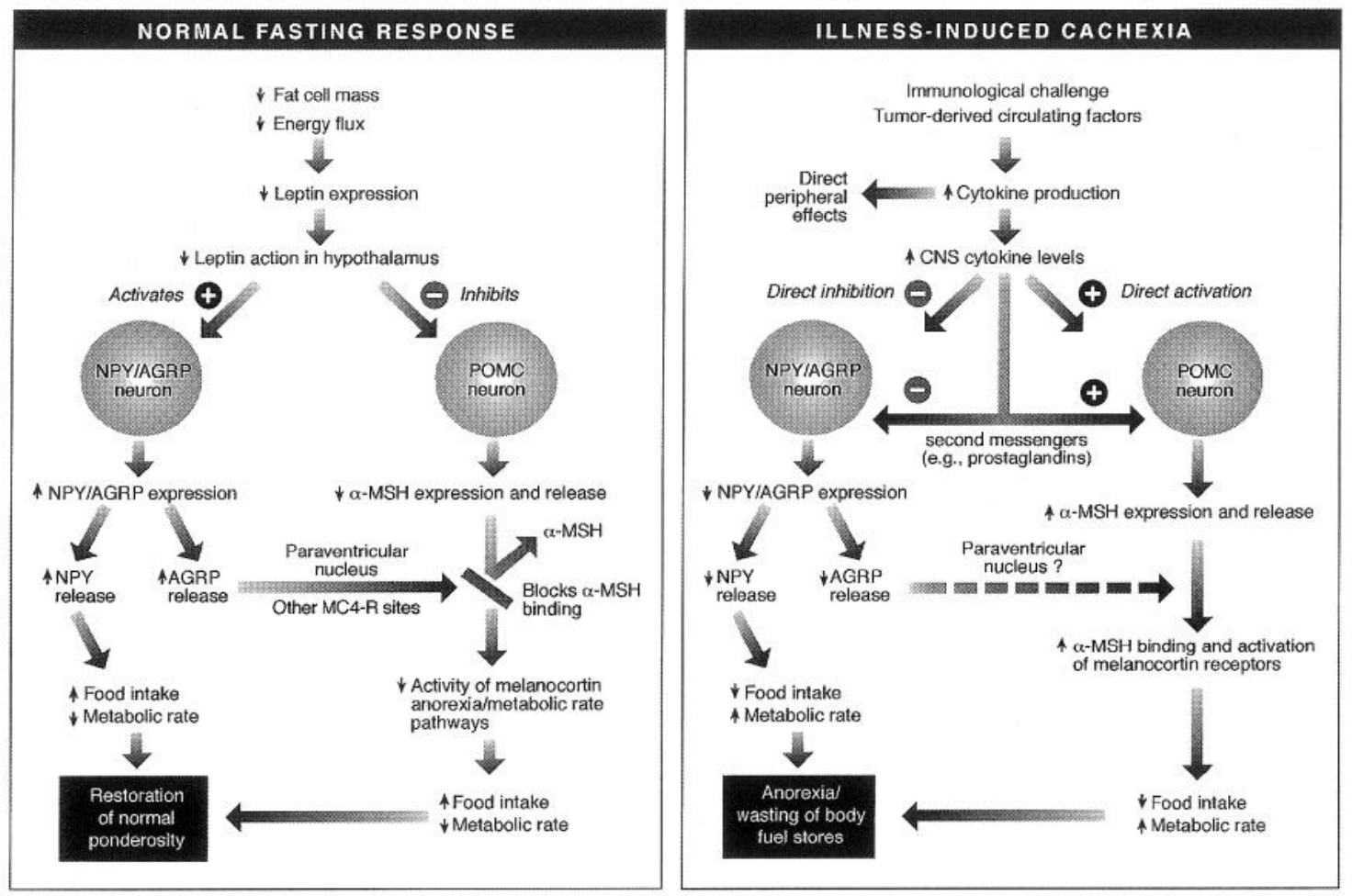

FIG. 1. Hypothetical models for the regulation of feeding and metabolic rate during normal fasting (left panel) and illness-induced cachexia. During illness, cytokines and other circulating factors result in activation of central anorexic/metabolic pathways, resulting in decreased energy intake and pathological wasting of body fuels, even in a relatively starved state (right panel). 
system may play a key role in the development of this pathological state (Huang, 1999). By analogy with the role of melanocortins in CNS-mediated obesity syndromes, we propose that stimuli that decrease feeding and cause a pathological wasting of body fuel stores exert their effects in part by enhancing signaling at hypothalamic melanocortin receptors (Figure 1). However, further studies will be required to elucidate the hormonal and neural pathways involved and to demonstrate the potential therapeutic role of melanocortin antagonists in treating anorexia and cachexia.

\section{ACKNOWLEDGMENTS}

The authors are grateful for the commentary and editorial assistance of Dr. Michael Cowley and for the laboratory assistance of Kathy Khong and Katie Miles.

\section{REFERENCES}

Adan, R.A.H., and Gispen, W.H. (1997). Peptides 18(6), 1-7.

Ahima, R., Prabakaran, D., Mantzoros, C., Qu, D., Lowell, B., Maratos-Flier, E., and Flier, J.S. (1996). Nature 382, 250-252.

Baile, C.A., Naylor, J., McLaughlin, C.L., and Catanzaro, C.A. (1981). Physiol. Behav. 27, 271-277. Baskin, D.G., Breininger, J.F., and Schwartz, M.W. (1999). Diabetes 48, 828-833.

Baumann, H., Morella, K.K., White, D.W., Dembski, M., Bailon, P.S., Kim, H., Lai, C., and Tartaglia, L.A. (1996). Proc. Natl. Acad. Sci.U.S.A. 93, 8374-8378.

Billington, C.J., Briggs, J.E., Grace, M., and Levine, A.S. (1991). Am. J. Physiol. 260, R321-R327.

Rlasquez, C., Jegou, S., Friard, O., Tonon, M.C., Fournier, A., and Vaudry, H. (1995). Neuroscience 68(1), 221-227.

Blum, W.F., Englaro, P., Hanitsch, S., Juul, A., Hertel, N.T., Muller, J., Skakkebaek, N.E., Heiman, M.L., Birkett, M., Attanasio, A.M., Kiess, W., and Rascher, W. (1997). J. Clin. Metab. 82, 2094-2100.

Boston, B.A., Blaydon, K.M., Varnerin, J., and Cone, R.D. (1997). Science 278, 1641-1644.

Broberger, C., Johansson, C., Schalling, M., and Hokfelt, T. (1998). Proc. Natl. Acad. Sci. U.S.A. 95, 15043-15048.

Bruera, E. (1997). Br. Med. J. 315, 1219-1222.

Bultman, S.J., Michaud, E.J., and Woychik, R.P. (1992). Cell 71, 1195-1204.

Campfield, L.A., Smith, F.J., Guisez, Y., Devos, R., and Burn, P. (1995). Science 269, 546-549.

Catania, A., and Lipton, J.M. (1993). Endocr. Rev. 14(5), 564-576.

Catania, A., Manfredi, M.G., Airaghi, L., and Lipton, J.M. (1992). Pharmacol. Res. 26(suppl. 2), $72-73$.

Cavaillon, J.M., and Haeffner-Cavaillon, N. (1990). Cytokine 2, 313-329.

Chance, W.T., Balasubramaniam, A., Thompson, H., Mohapatra, B., Ramo, J, and Fischer, J.E. (1996). Peptides 17, 797-801.

Chen, P., Li, C., Haskell-Luevano, C., Cone, R.D., and Smith, M.S. (1999). Endocrinology 140(6), 2645-2650

Cheung, C.C., Clifton, D.K., and Steiner, R.A. (1997). Endocrinology 138, 4489-4492.

Chua, S.C., Chung, W.K., Wu-Peng, X.S., Zhang, Y., Liu, S.-M., Tartaglia, L., and Leibel, R.L. (1996) Science 271, 994-996.

Clayton, P.E., Gill, M.S., Hall, C.M., Tillman, V., Whatmore, A.J., and Price, D.A. (1997). Clin. Endocrinol. 46, 727-733. 
Clement, K., Vaisse, C., Lahlou, N., Cabrol, S., Pelloux, V., Cassuto, D., Gourmelen, M., Dina, C., Chambaz, J., Lacorte, J.M., Basdevant, A., Bougneres, P., Lebouc, Y., Froguel, P., and Guy-Grand, B. (1998). Nature 392, 398-401.

Comuzzie, A.G., Hixson, J.E., Almasy, L., Mitchell, B.D., Mahaney, M.C., Dyer, T.D., Stern, M.P., MacCluer, J.W., and Blangero, J. (1997). Nature Genet. 15, 273-276.

Considine, R.V., Sinha, M.K., Heiman, M.L., Kriauciunas, A., Stephens, T.W., Nyce, M.R., Ohannesian, J.P., Marco, C.C., McKee, L.J., Bauer, T.L., and Caro, J.F. (1996). N. Engl. J. Med. 334, 292-295.

Cowley, M.A., Pronchuk, N., Fan, W., Dinulescu, D.M., Colmers, W.F., and Cone, R.D. (1999). Neuron 24(1), 155-163.

DeConno, F., Martini, C., Zecca, E., Balzarini, A., Venturino, P., Groff, L., and Caraceni, A. (1998). Eur. J. Cancer 34(11), 1705-1709.

Dinarello, C.A. (1996). Blood 87, 2095-2147.

Dinulescu, D.M. (2000). "The role of mahagony in melanocortin signaling," $\mathrm{PhD}$ dissertation, Oregon Health Sciences University, Portland, Ore.

Duhl, D.M., Stevens, M.E., Vrieling, H., Saxon, P.J., Miller, M.W., Epstein, C.J., and Barsh, G.S. (1994). Development 120(6), 1695-1708.

Egawa, M., Yoshimatsu, H., and Bray, G.A. (1991). Am. J. Physiol. 260, R328-R334.

Elmquist, J.K., Ahima, R.S., Maratos Flier, E., Flier, J.S., and Saper, C.B. (1997). Endocrinology 138, 839-842.

Emery, P.W. (1999). Nutrition 15, 600-603.

Emery, P.W., Lovell, L., and Rennie, M.J. (1984). Cancer Res. 44, $2779-2784$.

Erickson, J., Hollopeter, G., and Palmiter, J.D. (1996). Science 274, 1704-1707.

Faggioni, R., Fuller, J., Moser, A., Feingold, K.R., and Grunfeld, C. (1997). Am. J. Physiol. 273(42), R181-R186.

Fan, W., Boston, B.A., Kesterson, R.A., Hruby, V.J., and Cone, R.D. (1997). Nature 385, 165-168.

Fan, W., Dinulescu, D.M., Butler, A.A., Zhou, J., Marks, D.L., and Cone, R.D. (2000). Endocrinology 141(9), 3072-3079.

Farooqi, I.S., Jebb, S.A., Langmack, G., Lawrence, E., Cheetham, C.H., Prentice, A.M., Hughes, I.A., McCamish, M.A., and O'Rahilly, S. (1999). N. Engl. J. Med. 341(12), 879-884.

Finck, B.N., and Johnson, R.W. (1999). NeuroReport 10, 153-156.

Finck, B.N., Kelly, K.W., Dantzer, R., and Johnson, R.W. (1998). Endocrinology 139(5), 2278-2283.

Fong, T.M., Mao, C., MacNeil, C., Kalyani, R., Smith, T., Weinberg, D., Tota, M.R., and Van der Ploeg, L.H. (1997). Biochem. Biophys. Res. Commun. 237, 629-631.

Fong, Y., Moldawer, I.I., Marann, M., Wei, H, Barher, A., Manogue, K., Tracey, K.I., Kun, G., Fischman, D.A., Cerami, A., and Lowry, S.F. (1989). Am. J. Physiol. 256(25), R659-R665.

Friedman, J.M. (1997). Nature 385, 119-120.

Frigeri, L.G., Wolff, G.L., and Robel, G. (1983). Endocrinology 113, 2097-2105.

Frigeri, L.G., Wolff, G.L., and Teguh, C. (1988). Intl. J. Obesity 12, 305-320.

Gayle, D., Ilyin, S.E., Flynn, M.C., and Plata-Salaman, C.R. (1998). Brain Res. 795, 77-86.

Gerald, C., Walker, M.W., Criscione, L., Gustafson, E.L., Batzl-Hartmann, C., Smith, K.E., Vaysse, P., Durkin, M.M., Laz, T.M., Linemeyer, D.L., Schauffhauser, A.O., Whitebread, S., Hofbauer, K.G., Taber, R.I., Branchek, T.A., and Weinshank, R.L. (1996). Nature 382, 168-171.

Glaum, S.R., Hara, M., Bindokas, V.P., Lee, C.C., Polonsky, K.S., Bell, G.I., and Miller, R.J. (1997). Mol. Pharmacal. 50, 230-235.

Grill, H.J., Ginsberg, A.B., Seeley, R.J., and Kaplan, J.M. (1998). J. Neurosci. 18(23), 10128-10135.

Grunfeld, C., Zhao, C., Fuller, J., Pollock, A., Moser, A., Friedman, J., and Feingold, K.R. (1996). J. Clin. Invest. 97, 2152-2157.

Gura, T. (1997). Science 275, 751-753.

Hakansson, M.L., Hulting, A.L., and Meister, B. (1996). NeuroReport 7(18), 3087-3092. 
Halaas, J., Gajiwala, K., Maffei, M., Cohen, S., Chait, B., Rabinowitz, D., Lallone, R., Burley, S., and Friedman, J.M. (1995). Science 269, 543-546.

Halaas, J.L., Boozer, C., Blair-West, J, Fidahusein, N., Denton, D. A., and Friedman, J.M. (1997). Proc. Natl. Acad. Sci. U.S.A. 94, 8878-8883.

Haskell-Luevano, C., Chen, P., Li, C., Chang, K., Smith, M.S., Cameron, J.L., and Cone, R.D. (1999). Endocrinology 140, 1408-1415.

Hillhouse, E.W., and Mosley, K. (1993). Br. J. Pharmacol. 109, 289-290.

Huang, Q.H., Hruby, V.J., and Tatro, J.B. (1999). Am. J. Physiol. 276 (3 pt. 2), R864-R871.

Huszar, D., Lynch, C.A., Fairchild-Huntress, V., Dunmore, J.H., Fang, Q., Berkemeier, L.R., Gu, W., Kesterson, R.A., Boston, B.A., Cone, R.D., Smith, F.J., Campfield, L.A., Burn, P., and Lee, F. (1997). Cell 88, 131-141.

Inui, A. (1999a). Cancer Res. 59, 4493-4501.

Inui, A. (1999b). Trends Neurosci. 22(2), $62-67$.

Jacob, R.J., Dziura, J., Madwick, M., Leone, P., Caprio, S., During, M., Shulman, G.1., and Sherwin, R.S. (1997). Diabetes 46, 150-153.

Jensen, P.B., Blume, N., Mikkelsen, J.D., Larsen, P.J., Jensen, H.I., Holst, J.J., and Madsen, O.D. (1998). J. Clin. Invest. 101(2), 503-510.

Kalra, S.P., Dube, M.G., Pu, S., Xu, B., Horvath, T.L., and Kalra, P.S. (1999). Endocr. Rev. 20(1), 68-100.

Kotler, D.P., Tierney, A.R., Wang, J., and Pierson, R.N.J. (1989). Am. J. Clin. Nutrit. 50(3), 444-447.

Krude, H., Biebermann, H., Luck, W., Horn, R., Brabant, G., and Gruters, A. (1998). Nature Genet. 19, 155-157.

Larkin, M. (1998). Lancet 351, 1336.

Larsen, P.J., Tang-Christensen, M., and Cameron, J.L. (1997). Soc. Neurosci. Abst. 1997, 528.14.

Levine, A.S., and Morley, J.E. (1984). Peptides 5(6), 1025-1029.

Llovera, M., Garcia-Martinez, C., Lopez-Soriano, J., Agell, N., Lopez-Soriano, F.J., Garcia, I., and Argiles, J.M. (1998). Cancer Lett. 130, 19-27.

Loffreda, S., Yang, S.Q., Lin, II.Z., Karp, C.L., Brengman, M.L., Wang, D.J., Klein, A.S., Bulkley, G.B., Bao, C., Noble, P.W., Lane, M.D., and Diehl, A.M. (1998). FASEB J. 12(1), 57-65.

Lu, D., Willard, D., Patel, I.R., Kadwell, S., Overton, L., Kost, T., Luther, M., Chen, W., Woychik, R.P., Wilkison, W.O, and Cone, R.D. (1994). Nature 371, 799-802.

Luheshi, G.N., Gardner, J.D., Rushforth, D.A., Loudon, A.S., and Rothwell, N.J. (1999). Proc. Nat. Acad. Sci. U.S.A. 96(12), 7047-7052.

Marks, D.L., Miles, K.E., and Cone, R.D. (2000). In "Program \& Abstracts of the 1 lth International Congress of Endocrinology," October 30-November 2, 2000, Sydney, Australia

Marksteiner, J., and Sperk, G. (1988). Neuroscience 26(2), 379-385.

Marsh, D.J., Hollopeter, G., Huszar, D., Laufer, R., Yagaloff, K.A., Fisher, S.L., Burn, P., and Palmiter, R.D. (1999). Nature Genet. 21, 119-122.

Masotto, C., Caspani, G., Grazia de Simoni, M., Mengozzi, M., Scatturin, M., Sironi, M., Carenzi, A., and Ghezzi, P. (1992). Brain Res. Bull. 28, 161-165.

Matthys, P., Heremans, H., Opdenakker, G., and Billiau, A. (1991). Eur. J. Cancer 27(2), 182-187.

McCarthy, D.O. (1999). Res. Nurs. Health 22(5), 380-387.

Michaud, E.J., Bultman, S.J., Klebig, M.L., van Vugt, M.J., Stubbs, L.J., Russell, L.B., and Woychik, R.P. (1994). Proc. Natl. Acad. Sci. U.S.A. 91(7), 2562-2566.

Miller, M.W., Duhl, D. M. J., Vrieling, H., Cordes, S.P., Ollmann, M.M., Winkes, B.M., and Barsh, G.S. (1993). Genes Devel. 7, 454-467.

Mizuno, T.M., and Mobbs, C.V. (1999). Endocrinology 140(2), 814-817.

Molloy, R.G., Mannick, J.A., and Rodrick, M.L. (1993). Br. J. Surg. 80, 289-297. 
Montague, C.T., Farooqi, I.S., Whitehead, J.P., Soos, M.A., Rau, H., Wareham, N.J., Sewter, C.P., Digby, J.E., Mohammed, S.N., Hurst, J.A., Cheetham, C.H., Earley, A.R., Barnett, A.H., Prins, J.B, and O'Rahilly, S. (1997). Nature 387, 903-908.

Mountjoy, K.G., Mortrud, M.T., Low, M.J., Simerly, R.B., and Cone, R.D. (1994). Mol. Endocrinol. 8, 1298-1308

Murray, M.J., and Murray, A.B. (1979). Am. J. Clin. Nutrit. 32, 593-596.

Ollmann, M.M., Wilson, B.D., Yang, Y.-K., Kerns, J.A., Chen, Y., Gantz, I., and Barsh, G.S. (1997). Science 278, 135-137.

Ozata, M., Ozdemir, C., and Licinio, J. (1999). J. Clin. Endocrinol. Metab. 84(10), 3686-3695.

Patterson, T.A., Hedde, J.R., She, L., Newsome, W.P., and Cornelius, P. (1999). Soc. Neurosci. Abst. 25,618 .

Pelleymounter, M., Cullen, M., Baker, M., Hecht, R., Winters, D., Boone, T., and Collins, F. (1995). Science 269, 540-543.

Plata-Salaman, C.R. (1989). Brain Behav. Immunol. 3, 193-213.

Plata-Salaman, C.R. (1998). Psychoneuroendocrinology 24, 25-41.

Plata-Salaman, C.R., and Borkoski, J.P. (1994). Am. J. Physiol. 266, R1711-R1715.

Plata-Salaman, C.R., Sonti, G., Borkoski, J.P., Wilson, C.D., and Ffrench-Mullen, J.M.H. (1996). Phys. Behav. 60, 867-875.

Plata-Salaman, C.R., Ilyin, S.E., and Gayle, D. (1998). Am. J. Physiol. 275, R566-R573.

Rivandeneria, D.E., Naama, H.A., McCarter, M.D., Fujita, J., Evoy, D., Mackrell, P., and Daly, J.M. (1999). Nutrit. Cancer 35(2), 202-206.

Roemmich, J.N., and Rogol, A.D. (1999). Endocrinol. Metab. Clin. N. Am. 28(4), 749-764.

Roselli-Rehfuss, L., Mountjoy, K.G., Robbins, L.S., Mortrud, M.T., Low, M.J., Tatro, J.B., Entwistle, M.L., Simerly, R., and Cone, R.D. (1993). Proc. Natl. Acad. Sci. U.S.A. 90, 8856-8860.

Rossi, M., Kim, M.S., Morgan, D.G., Small, C.J., Edwards, C.M., Sunter, D., Abusnana, S., Goldstone, A.P., Russell, S.H., Stanley, S.A., Smith, D.M., Yagaloff, K., Ghatei, M.A., and Bloom, S.R. (1998). Endocrinology 139(10), 4428-4431.

Sarraf, P., Frederich, R.C., Turner, E.M., Ma, G., Jaskowiak, N.T., Rivet, D.J.I., Flier, J.S., Lowell, B.B., Fraker, D.L., and Alexander, H.R. (1997). J. Exp. Med. 185(1), 171-175.

Sherry, B.A., Gelin, J., Fong, Y., Marano, M., Wei, H., Cerami, A., Lowry, S.F., Lundholm, K.G., and Moldawer, L.L. (1989). FASEB J. 3, 1956-1962.

Shimomura, Y., Inukai, T., Kuwabara, A., Shimizu, H., Sato, N., Uehara, Y., Kobayashi, I., and Kobayashi, S. (1991). Eur. J. Pharmacol. 209, 15-18.

Shutter, J.R., Graham, M., Kinsey, A.C., Scully, S., Luthy, R., and Stark, K.L. (1997). Genes Devel. $11,593-602$.

Smith, M.S. (1993). Endocrinology 133, 1258-1265.

Stair, J.N., Shu, J., Camacho, R., Murphy, B., Hickey, G.J., MacIntyre, D.E., and Strack, A.M. (1999). Soc. Neurosci Abst. 25, 619.

Stanley, B.G., Chin, A.S., and Leibowitz, S.F. (1985). Brain Res. Bull. 14, 521-524.

Stephens, T.W., Basinsky, M., Bristow, P.K., Bue-Valleskey, J.M., Burgett, S.G., Craft, L., Hale, J., Hoffmann, J., Hsiung, H.M., Kriauciunas, A., Mackeller, W., Rosteck, P.R., Schoner, B., Smith, D., Tinsley, F.C., Zhang, X.-Y., and Heiman, M. (1995). Nature 377, 530-532.

Strang, P. (1997). Anticancer Res. 17(1b), 657-662.

Svaninger, G., Drott, C., and Lundholm, K. (1987). J. Natl. Cancer Inst. 78, 943-950.

Svaninger, G., Gelin, J., and Lundholm, K. (1989). Eur. J. Cancer Clin. Oncol. 25(9), 1295-1302.

Tartaglia, L.A., Dembski, M., Weng, X., Deng, N., Culpepper, J., Devos, R., Richards, G.J., Campfield, L.A., Clark, F.T., Deeds, J., Muir, C., Sanker, S., Moriarty, A., Moore, K.J., Smutko, J.S., Mays, G.G., Woolf, E.A., Monroe, C.A., and Tepper, R.I. (1995). Cell 83, 1263-1271.

Tatro, J.B., Huszar, D., Fairchild-Huntress, V., and Huang, Q.H. (1999). Soc. Neurosci. Abst. 25(624.4), 1558. 
Tisdale, M.J. (1997). J. Natl. Cancer Inst. 89, 1763-1773.

Ushmorov, A., Hack, V., and Droge, W. (1999). Cancer Res. 59, 3527-3534.

Vaisse, C., Clement, K., Guy-Grand, B., and Froguel, P. (1998). Nature Genet. 20, 113-114.

Vallieres, L., and Rivest, S. (1997). J. Neurochem. 69, 1668-1683.

Van Dam, A.M., Bauer, J., Tilders, F.J., and Berkenbosch, F. (1995). Neuroscience 65, 815-826.

Wang, Y., Kuropatwinski, K.K., White, D.W., Hawley, T.S., Hawley, R.G., Tartaglia, L.A., and Baumann, H. (1997). J. Biol. Chem. 272(26), 16216-16233.

Watts, A.G., Sanchez-Watts, G., and Kelly, A.B. (1999). J. Neurosci. 19(14), 6111-6121.

Wilding, J.P.H., Gilbey, S.G., Bailey, C.J., Batt, R.A.L., Williams, G., Ghatei, M.A., and Bloom, S.R. (1993). Endocrinology 132, 1939-1944.

Windisch, P., Papatheofanis, F.J., and Matuszewski, K.A. (1998). Ann. Pharmacother. 32(4), 437-445.

Wolff, G.L. (1963). Genetics 48, 1041-1058.

Wolff, G.L., and Flack, J.D. (1971). Nature 232, 181-182.

Woods, A.J., and Stock, M.J. (1996). Nalure 381, 745 .

Yasumoto, K., Mukaida, N., Harada, A., Kuno, K., Akiyama, M., Nakashima, E., Fujioka, N., Mai, M., Kasahara, T., and Fujimoto-Ouchi, K. (1995). Cancer Res. 55(4), 921-927.

Yen, T.T., Gill, A.M., Frigeri, L.G., Barsh, G.S., and Wolff, G.L. (1994). FASEB J. 8(8), 479-488.

Yeo, G.S.H., Farooqi, I.S., Aminian, S., Halsall, D.J., Stanhope, R.G., and O'Rahilly, S. (1998). Nature Genet 20,111-112.

Zhang, F.M., Basinski, M.B., and Beals, J.M. (1997). Nature 387, 206-209.

Zhang, Y., Procnca, R., Maffci, M., Baronc, M., Lcopold, L., and Fricdman, J.M. (1994). Nature 372, 425-432. 
